\title{
Aplikasi Metode Magnetotellurik Untuk Pendugaan Reservoir Panas Bumi (Studi Kasus: Daerah Mata Air Panas Cubadak, Sumatera Barat)

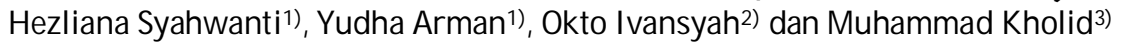

\author{
1)Program Studi Fisika, FMIPA UNTAN Pontianak \\ 2) Politeknik Negeri Pontianak \\ 3)Kelompok Penyelidikan Bawah Permukaan, PSDG \\ *Email: hezlyie@yahoo.com
}

\begin{abstract}
Abstrak
Data hasil perekaman dengan metode magnetotellurik di daerah mata air panas Cubadak, Sumatera Barat telah diolah dengan perangkat lunak pengolahan data MT. Hasil pengolahan data berupa gambar sebaran resistivitas pada lintasan yang dipilih terhadap kedalaman. Letak batuan penudung, reservoir dan patahan dapat ditentukan pada gambar lintasan tersebut. Hasil pengolahan data berupa pemodelan yang ditampilkan dalam gambar nilai resistivitas terhadap kedalaman dan jarak antar titik ukur pada lintasan yang telah ditentukan. Lintasan yang digunakan ada dua yaitu lintasan Uutara-Selatan dengan 6 titik ukur dan lintasan Barat Daya-Timur Laut dengan 7 titik ukur. Pada lintasan utara-selatan dapat diduga adanya potensi panas bumi diantara titik ukur MTCB-16 dan MTCB-22 pada kedalaman 1000 meter yang ditunjukkan dengan penurunan resistivitas dari 35-61 $\Omega \mathrm{m}$ menjadi 15-27 $\Omega \mathrm{m}$. Pada lintasan barat dayatimur laut terdapat penurunan resistivitas dari 20-200 $\Omega$ m menjadi 5-12 $\Omega \mathrm{m}$ di kedalaman 1000 meter yang diduga sebagai batuan penudung pada sistem panas bumi di daerah mata air panas Cubadak.
\end{abstract}

Kata kunci : Panas Bumi, Metode Magnetotellurik, Mata Air Panas

\section{Latar Belakang}

Energi panas bumi merupakan salah satu sumber energi masa depan. Salah satu pemanfaatan energi panas bumi di Indonesia adalah sebagai energi listrik untuk penerangan. Namun, pengggunaan energi panas bumi sebagai pembangkit tenaga listrik hanya sekitar 3\% dan pemanfaatan energi panas bumi secara langsung masih belum optimal (Gaffar, et,al., 2007), sementara potensi energi panas bumi di Indonesia cukup besar. Berdasarkan berita media elektronik bahwa terdapat $40 \%$ cadangan panas bumi di Indonesia dari cadangan total dunia dan Indonesia merupakan negara yang memiliki cadangan panas bumi terbesar di dunia (Ika, 2014).

Pencarian panas bumi di beberapa daerah di Indonesia telah dilakukan. Berbagai metode pernah diterapkan untuk mengetahui letak dari energi panas bumi di daerah tersebut. Metode yang telah dilakukan adalah metode geolistrik, gravitasi dan magnetik. Penggunaan metodemetode tersebut masih memiliki kekurangan sehingga data mengenai lokasi panas bumi masih belum terperinci seperti kedalaman yang digambarkan dari hasil metode-metode tersebut masih dangkal. Perlu adanya suatu metode yang dapat memetakan kondisi bawah permukaan secara lebih dalam. Metode yang saat ini sedang berkembang di Indonesia untuk pencarian lokasi energi panas bumi adalah metode magnetotelurik (Kadir 2011).

Parameter yang akan dianalisis dari hasil pengukuran dengan metode ini adalah parameter resistivitas semu dan fase. Berdasarkan data pemetaan resistivitas bawah permukaan tersebut, selanjutnya akan diketahui perkiraan mengenai susunan sistem panas bumi yaitu reservoir panas bumi, lokasi clay cap dan lokasi komponen sistem panas bumi lainnya di bawah permukaan. Metode MT dapat digunakan di daerah yang memiliki manifestasi permukaan seperti mata air panas. Salah satu daerah yang memiliki mata air panas adalah Cubadak.

Cubadak merupakan daerah yang terletak di Kabupaten Pasaman, Provinsi Sumatera Barat (lihat gambar 1). Berdasarkan letak geografisnya, Cubadak terletak di koordinat 597600-617700 mT dan 21200-42500 mU (PSDG, 2011). Berdasarkan hasil kelompok program penelitian panas bumi diketahui bahwa diperkirakan temperatur bawah permukaan yang berhubungan dengan reservoir panas bumi adalah sebesar $235^{\circ} \mathrm{C}$ berdasarkan perhitungan geotermometri (PSDG, 2009). Sehingga dibutuhkan suatu informasi lanjutan untuk mengetahui batas reservoir dan konseptual model dari panas bumi di daerah mata air panas Cubadak. 


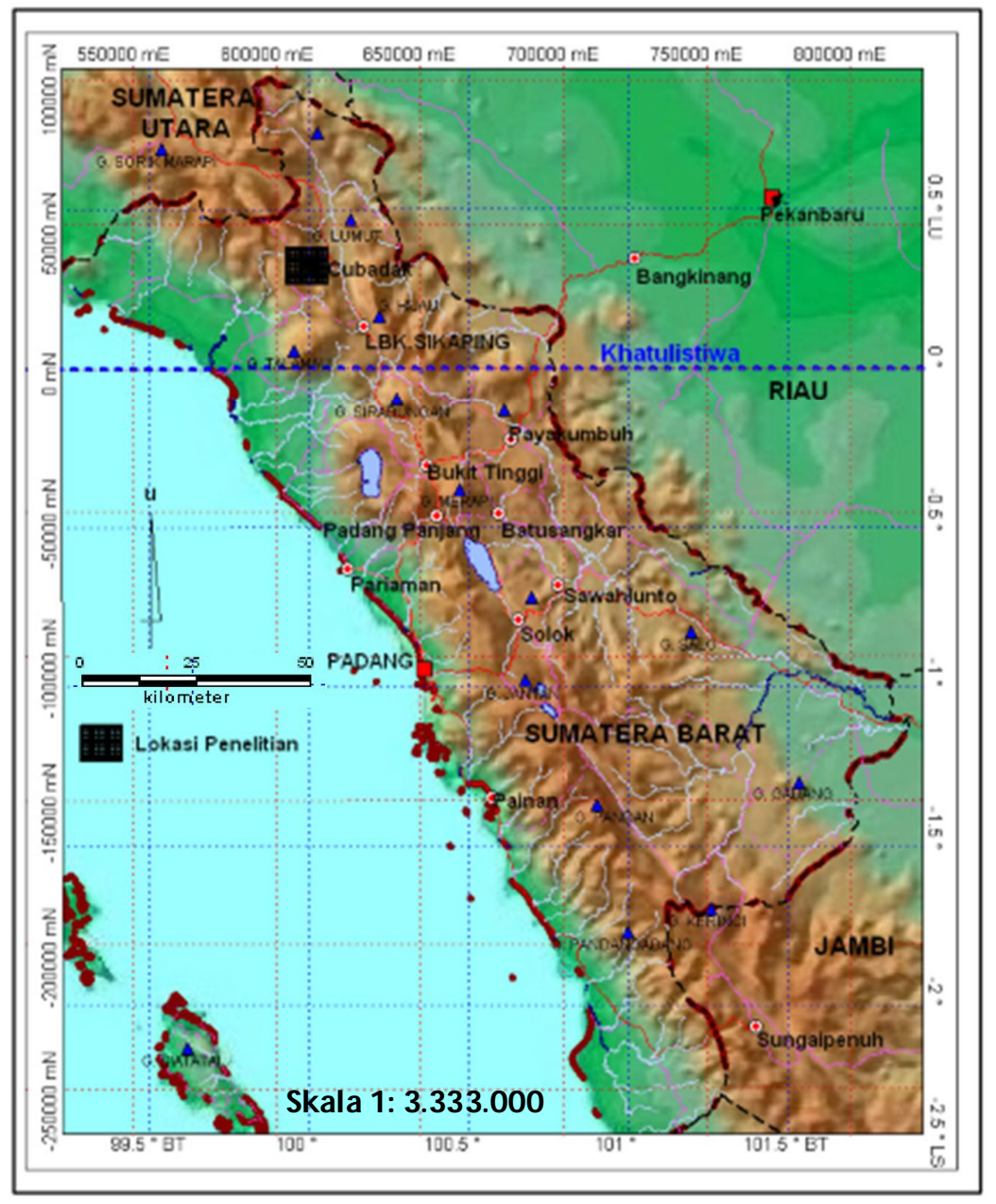

Gambar 1. Peta Lokasi Cubadak (Nurhadi dkk, 2009)

\section{Metodologi}

Metode MT adalah metode sounding yang mengukur secara pasif gelombang Elektromagnetik (EM) alami (Agung, 2009; Satrio dan Koesuma 2012). Metode magnetotellurik memiliki jangkauan penetrasi yang lebih dalam dibandingkan dengan metode geolistrik. Metode magnetotelurik dapat mengetahui sebaran batuan dan lapisan di bawah permukaan dengan melihat nilai resistivitasnya atau tahanan jenisnya (Kadir, 2011). Selain itu model konseptual, luas dan batas reservoir panas bumi dapat diketahui.

Sumber sinyal untuk metode magnetotellurik adalah medan magnetik yang berasal dari dalam dan luar bumi serta memiliki rentang frekuensi yang bervariasi. Medan magnet yang berasal dari dalam dikarenakan pergerakan antara mantel bumi terhadap inti bumi. Medan magnet yang berasal dari luar bumi adalah medan magnet yang dihasilkan di atmosfer dan magnetosfer (Agung, 2009; Kadir, 2011). Semua sumber medan magnetik tersebut memiliki nilai yang bervariasi terhadap waktu, tetapi yang dimanfaatkan pada Metode Magnetotellurik hanya medan magnetik yang berasal dari luar bumi yang memiliki rentang frekuensi lebih besar.

Sumber magnetik yang berasal dari luar bumi yaitu seperti peristiwa petir yang menyambar dan solar wind yang terjadi. Frekuensi yang dihasilkan oleh peristiwa solar wind memiliki frekuensi lebih kecil dari $1 \mathrm{~Hz}$ sehingga jarak tembus medan magnetik menjangkau kedalaman yang cukup jauh (Simpson dan Bahr, 2005). Frekuensi yang dihasilkan pada aktivitas petir atau kilat ialah di atas $1 \mathrm{~Hz}$ (Agung, 2009; Kadir, 2011). Peristiwa ini terjadi di ionosfer dan menjalar hingga ke permukaan bumi. Ketika mencapai permukaan bumi secara otomatis medan magnet bumi akan mengalami perubahan. Jika perubahan medan magnet bumi terjadi berulang kali maka akan menghasilkan fluks magnet yang menginduksi arus listrik di bawah permukaan bumi dan 
menghasilkan medan magnet sekunder yang akan direkam oleh alat MT (Kadir, 2011).

Gelombang EM yang masuk ke dalam permukaan bumi akan mengalami peluruhan dari amplitudo awal yang disebut dengan istilah skin depth. Skin depth adalah jarak $(\delta)$ sepanjang kuat medan listrik yang teratenuasi oleh kuat medan listrik awal. Skin depth dapat dituliskan dengan persamaan berikut (Kadir, 2011):

$$
\delta=\sqrt{\frac{2}{\omega \sigma \mu}} \approx 503 \sqrt{\frac{\rho}{f}}
$$

Keterangan :

$\rho=$ resistivitas

$\mathrm{f}=$ frekuensi

Frekuensi yang digunakan pada metode MT adalah antara $10^{-4} \mathrm{~Hz}$ hingga $10^{4} \mathrm{~Hz}$ (Satrio dan Koesuma, 2012).

Waktu perekaman data biasanya dilakukan hingga belasan jam agar data yang terukur cukup untuk menggambarkan kondisi di bawah permukaan hingga kedalaman ribuan meter. Alat MTU akan merekam variasi waktu dari medan magnet dan medan listrik yang akan disimpan dalam removable flash card (Kadir, 2011). Sensor yang digunakan untuk merekam data terdiri dari 2 jenis sensor yaitu sensor elektrik dan sensor magnetik. Sensor elektrik berfungsi untuk merekam data medan listrik dan sensor magnetik berfungsi untuk merekam data medan magnet. Terdapat 3 sensor magnetik yang terdiri dari 3 koil ( $\mathrm{Hx}, \mathrm{Hy}$ dan $\mathrm{Hz}$ ) dimana 2 sensor magnetik akan diletakkan secara horizontal dan 1 sensor magnetik diletakkan secara vertical. Sensor elektrik yang digunakan terdiri dari 5 poros pot, dimana 4 buah poros pot akan diletakkan secara tegak lurus (Ex dan Ey) dan 1 buah akan ditanam di bawah alat MTU sebagai ground. Pada setiap sensor akan terhubung dengan kabel connector untuk menghubungkan 3 buah koil dan 5 poros pot ke alat MTU. Laptop akan digunakan untuk mengoperasikan alat MTU dan melihat data mentah, mentransfer data ke removable flash card. Pada proses pengukuran akan digunakan GPS untuk mengetahui posisi pengukuran di titik tersebut. Akumulator akan dimanfaatkan sebagai sumber energi listrik untuk mengaktifkan alat MTU. Converter AC-DC digunakan untuk megubah tegangan pada akumulator sebagai energi untuk mengaktifkan laptop.

Poros pot akan ditanam pada lubang. Lubang yang akan ditempati harus di isi dengan larutan bentronit. Larutan bentronit adalah larutan yang terdiri dari bentonit, garam dan akuades. Ini berfungsi agar lokasi penanaman tersebut lebih bersifat elektrolit sehingga elektrode dapat merekam arus tellurik secara maksimal.

Sebelum penempatan alat pada lokasi pengukuran, dilakukan kalibrasi alat terlebih dahulu. Kalibrasi dilakukan di daerah yang memiliki sedikit gangguan seperti terhindar dari sumber-sumber listrik dan ground motion. Pertama-tama GPS dan laptop dihubungkan ke alat MTU. Kemudian MTU dihubungkan ke koil yang disusun sejajar di atas tanah. Setalah itu MTU akan mengukur dalam waktu 30-60 menit. Setelah itu baru dapat dilakukan pengukuran ke titik yang ditentukan. Pada proses pengaturan alat sesuai layout pengukuran, poros pot diletakkan kurang lebih dengan jarak 100 meter antar poros pot.

Setelah itu dapat dilakukan proses perekaman data. Pada proses ini, kontak antara poros pot dengan tanah harus diperiksa terllebih dahulu. Nilai resistivitas harus relative lebih kecil dari $2 \mathrm{k} \Omega$. setelah semua siap maka proses perekaman data dapat dilakukan. Parameter yang ingin diukur dapat ditententukan dengan menggunakan laptop.

Data yang telah direkam pada alat MTU berupa data mentah medan listrik dan medan magnet terhadap waktu. Pemilihan pada interval waktu pengukuran mempengaruhi kualitas data. Semakin panjang interval waktu maka jumlah data yang didapat semakin banyak. Setelah itu data dalam domain waktu akan diubah menjadi domain frekuensi dengan transformasi fourier. Proses transformasi fourier dilakukan karena parameter fisis seperti impedansi, resistivitas semu dan fase merupakan fungsi frekuensi (Heditama, 2011). Setelah itu akan dihitung nilai impedansi, resistivitas semu dan fase dengan menggunakan robust processing. Robust processing digunakan untuk mengurangi noise dan membuat data lebih baik (Heditama, 2011). Semua proses tersebut dilakukan di perangkat lunak SSMT 2000 . 


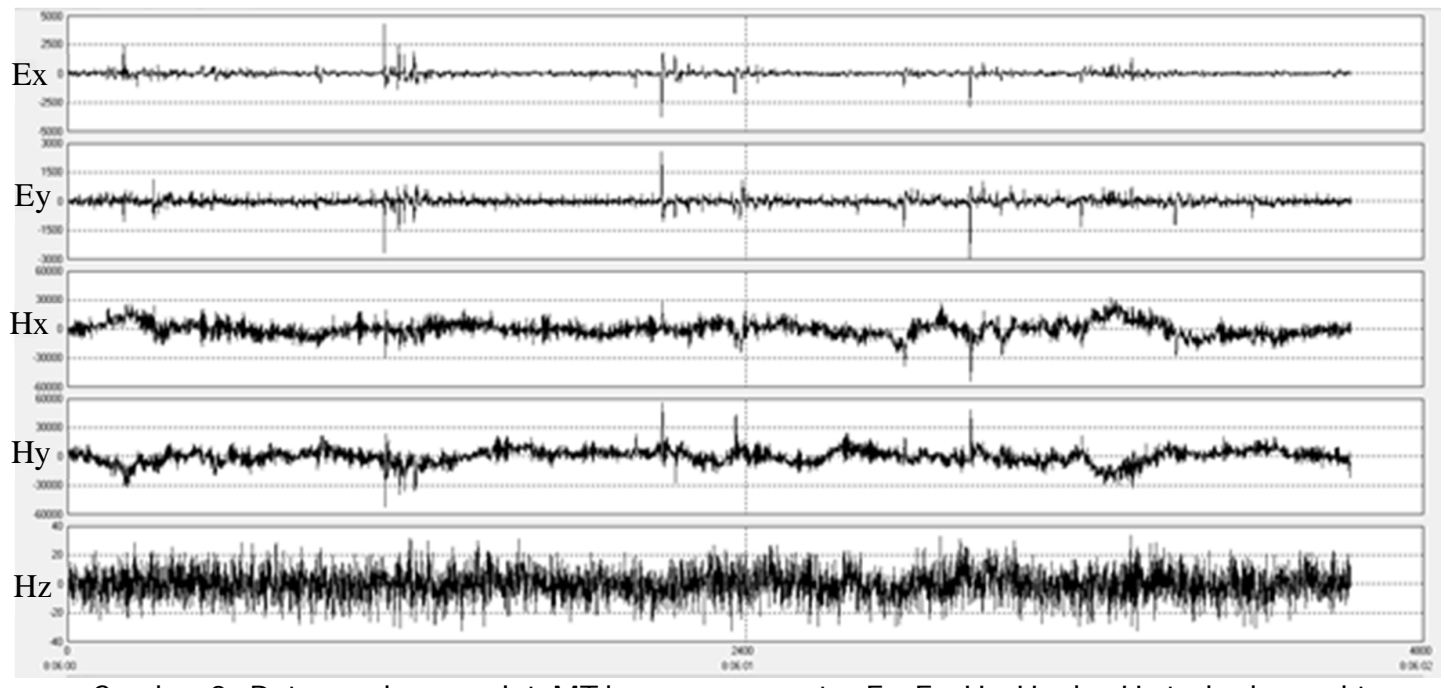

Gambar 2 . Data perekaman alat MT berupa parameter Ex, Ey, Hx, Hy dan Hz terhadap waktu

Kemudian pengolahan data magnetotellurik dilanjutkan dengan membuat inversi dari data lintasan pengukuran. Persamaan forward modelling untuk metode MT adalah (Grandis, 1997):

$$
Z_{j}=Z_{0 j} \frac{1-R_{j} e_{j}^{\left(-2 k_{j} h_{j}\right)}}{1+R_{j} e_{j}^{\left(-2 k_{j} h_{j}\right)}}
$$

dimana $\quad R_{j}=\frac{Z_{0 j}-Z_{j+1}}{Z_{0 j}+Z_{j+1}}, k_{j}=\sqrt{\frac{\overline{i \omega \mu_{0}}}{\rho_{j}}}$

Keterangan :

$\mathrm{Z}=$ Impedansi

$\mathrm{h}=$ Kedalaman

$\mathrm{k}=$ Bilangan gelombang

$\mathrm{R}=$ Impedansi kontinyu

$\omega=$ Kecepatan sudut gelombang

$\mu_{0}=$ Pemitivitas ruang hampa

Persamaan (2) adalah rumus rekrusif yang menyatakan impedansi di lapisan -j sebagai fungsi parameter $\rho_{j}$ dan $\mathrm{h}_{\mathrm{j}}$ dan impedansi permukaan lapisan di bawahnya (lapisan $-\mathrm{j}+1$ ). Jadi impedansi permukaan bumi $\left(Z_{j}\right)$ dapat dihitung.

Pengolahan data selenjutnya dengan menggunakan inversi NLCG (Non Linear Conjugate Gradient). Persamaan model untuk metode ini adalah (Amriyah, 2012) :

$$
m_{k+1}=m_{k}+\alpha_{k} U_{k}
$$

dimana nilai $\mathrm{U}_{\mathrm{k}}=\mathrm{M}_{\mathrm{k}}{ }^{-1}\left(-\nabla \mathrm{W}\left(\mathrm{m}_{\mathrm{k}}\right)\right) . \mathrm{M}_{\mathrm{k}}$ merupakan sistem pre-conditioner. Persamaan tersebut digunakan untuk proses update model, dimana nilai $\alpha$ dicari terlebih dahulu untuk meminimalisirkan fungsi $\mathrm{W}\left(\mathrm{m}_{\mathrm{k}}+\alpha_{\mathrm{k}} \mathrm{U}_{\mathrm{k}}\right)$. Pada proses komputasi, algoritma tersebut dikendalikan oleh jumlah iterasi $\left(\mathrm{N}_{\mathrm{cg}}\right)$. $\mathrm{N}_{\mathrm{cg}}$ merupakan fungsi dari $\lambda$ dimana nilai $\lambda$ yang besar akan membutuhkan jumkah $\mathrm{N}_{\mathrm{cg}}$ yang kecil, begitu sebaliknya (Siripunvaraporn, 2006). Hasil pengolahan data dengan inversi tersebut adalah berupa gambar 2 dimensi.

\section{Hasil dan Pembahasan}

Hasil pengolahan data metode magnetotellurik satu dimensi berupa grafik resistivitas semu dan fase terhadap frekuensi (grafik MT). Berdasarkan gambar 3. terlihat adanya gangguan pada data pengukuran dengan melihat jarak antara grafik Rhoxy dan grafik Rhoyx yang cukup jauh. Sehingga dilakukan pengolahan data pada grafik tersebut. Gambar 4 . merupakan hasil pengolahan data dengan gangguan pada data yang telah berkurang. 


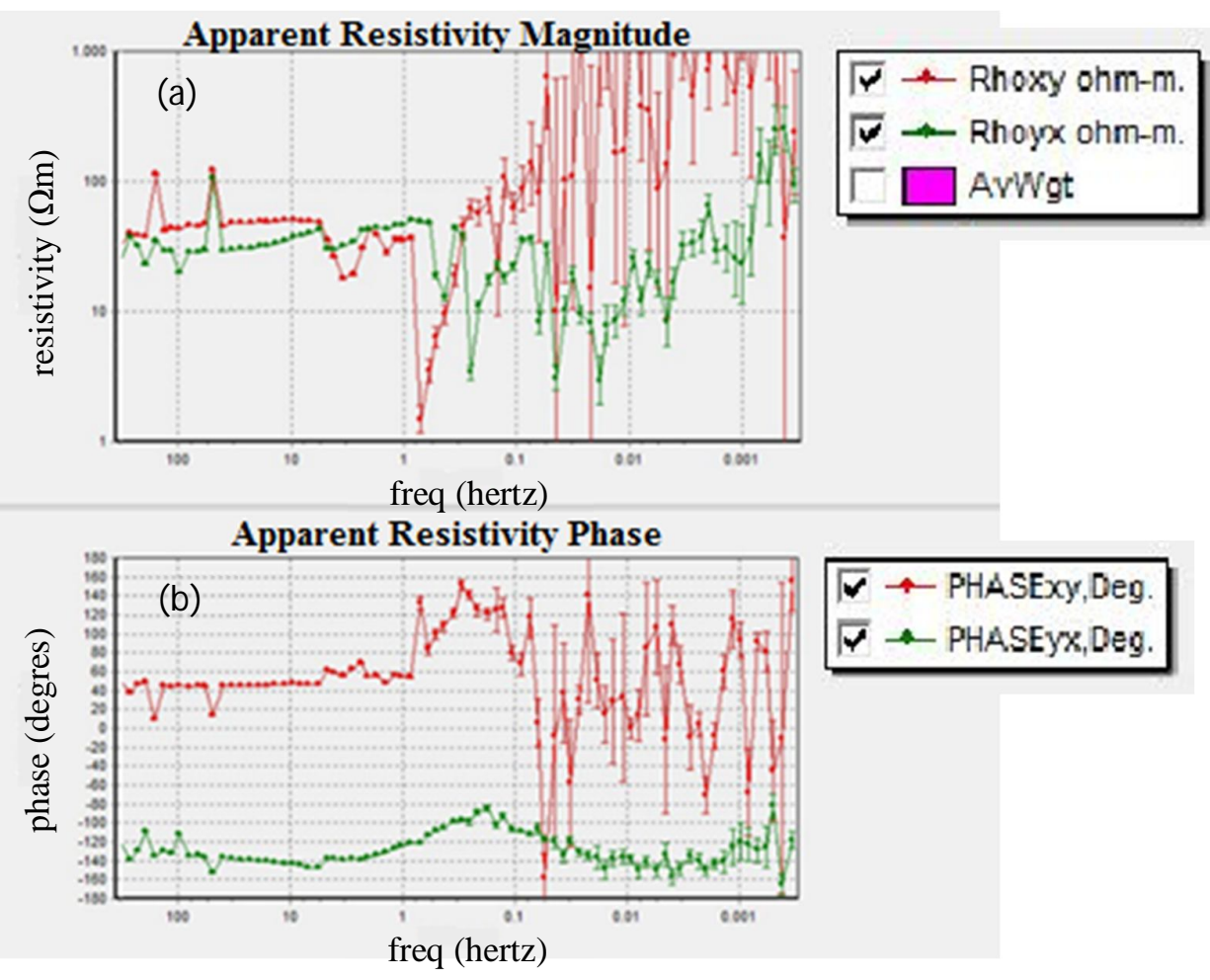

Gambar 3. Grafik MT sebelum diedit: (a) Frekuensi terhadap resistivitas semu; (b) Frekuensi terhadap fase

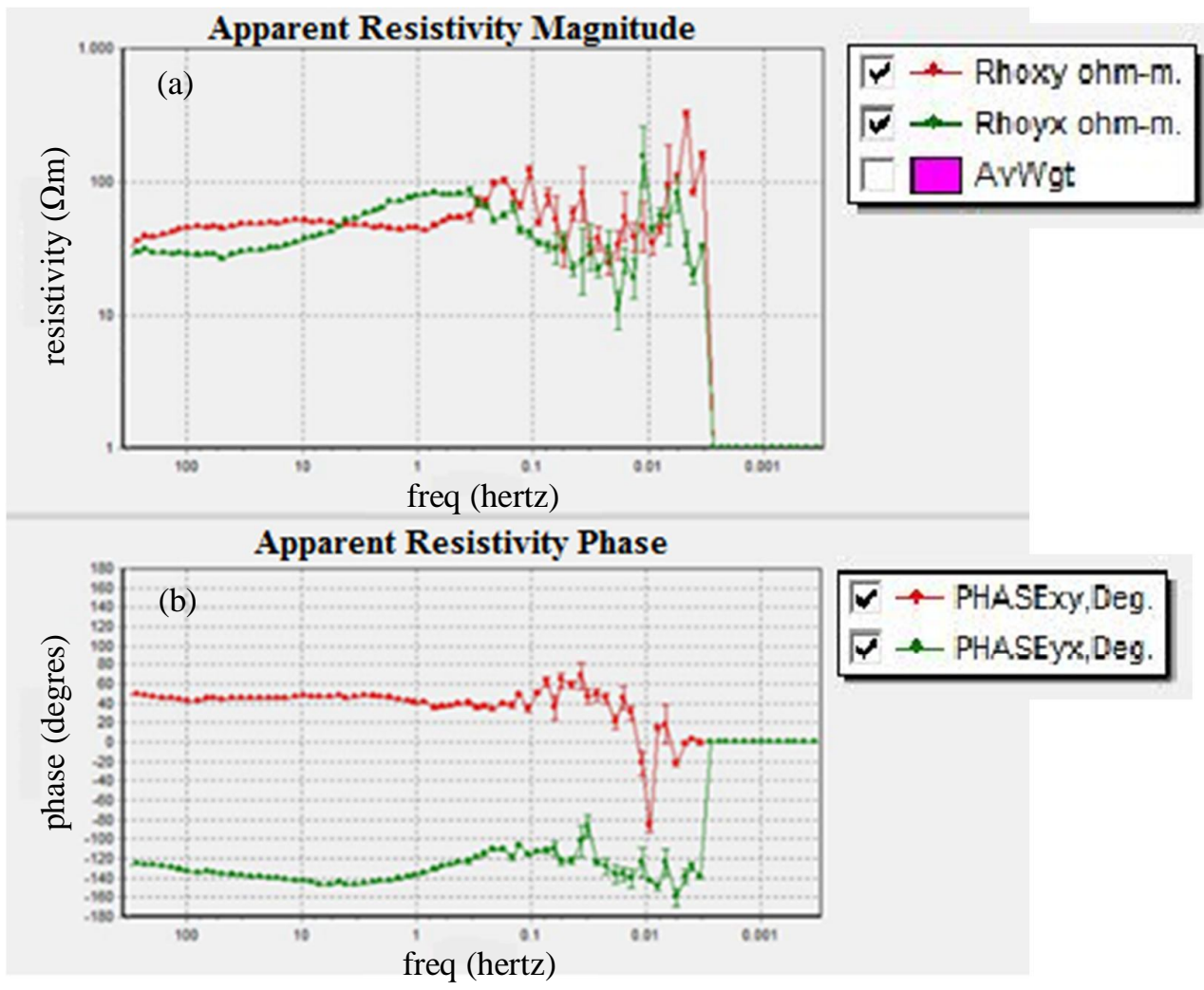

Gambar 4. Grafik MT setelah diedit: (a) Frekuensi terhadap resistivitas semu; (b) Frekuensi terhadap fase 
Data satu dimensi pada satu titik pengukuran tersebut akan di inversi dan digabungkan dengan data titik pengukuran lainnya untuk menjadi satu lintasan. Hasil pengolahan inversi data berupa gambar 2 dimensi nilai resistivitas terhadap kedalaman.

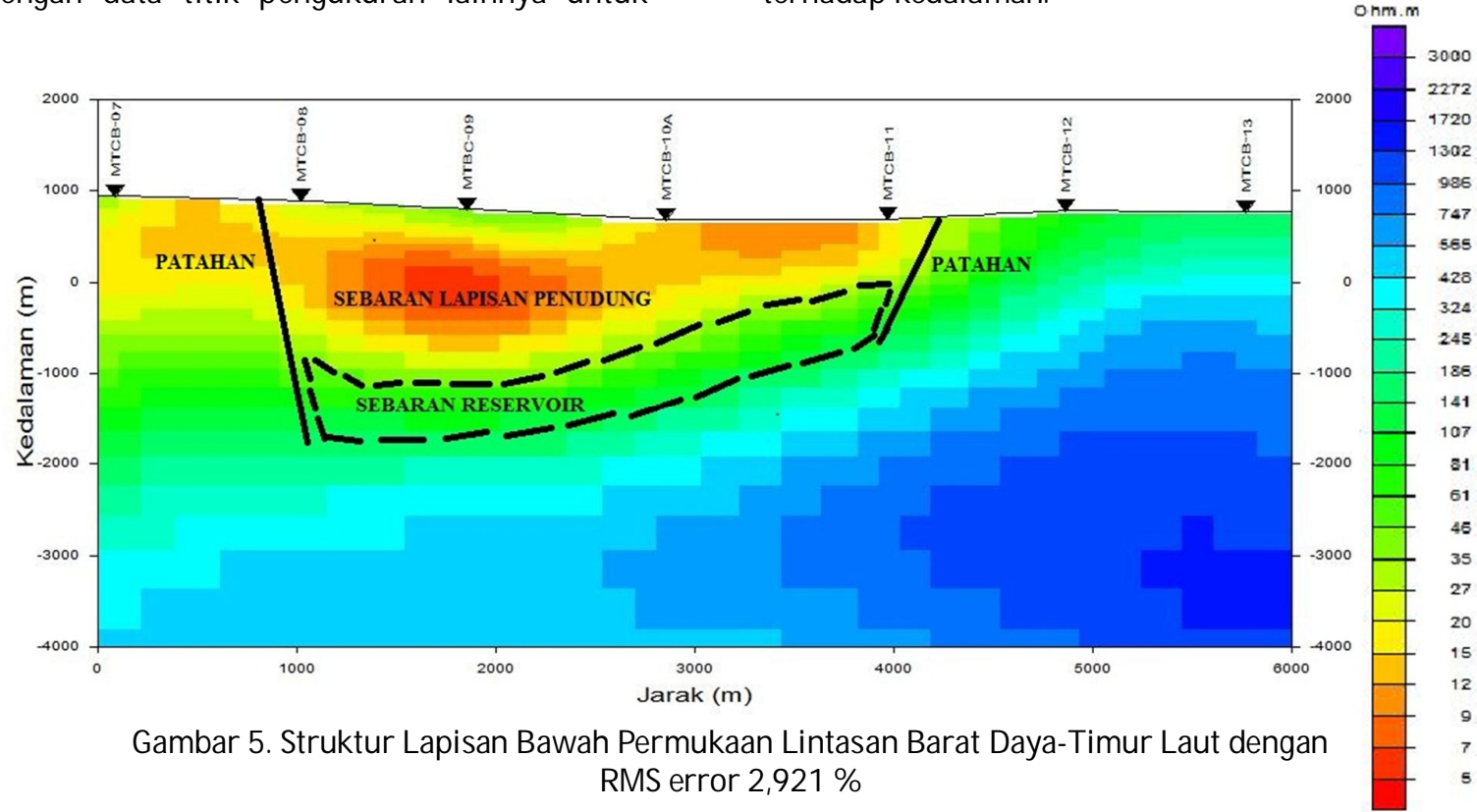

Berdasarkan gambar 5. terlihat bahwa dari lapisan permukaan nilai resistivitas berada pada rentang nilai $20 \Omega \mathrm{m}$ sampai dengan $200 \Omega \mathrm{m}$. Tetapi semakin dalam terdapat penurunan nilai resistivitas secara drastis. Nilai resitivitas menurun menjadi $5 \Omega \mathrm{m}$ sampai dengan $12 \Omega \mathrm{m}$ pada kedalaman kurang lebih 1000 meter. Ini menunjukkan pada kedalaman tersebut terdapat dugaan sebaran batuan penudung panas bumi. Berdasarkan susunan komponen panas bumi, maka di bawah sebaran batuan penudung, diduga sebagai sebaran reservoir pada lintasan tersebut dengan nilai resistivitas berada di antara $60 \Omega \mathrm{m}$ sampai dengan $180 \Omega \mathrm{m}$. Batuan dasar yang terdapat di bawah sebaran reservoir memiliki nilai resistivitas $300 \Omega \mathrm{m}$ sampai dengan $700 \Omega \mathrm{m}$

Lapisan penudung atau batuan penudung terbentuk karena adanya proses hidrotermal yaitu proses yang terjadi akibat reaksi antara batuan asal dengan fluida panas bumi (Saptaji, 2001). Semakin dalam nilai resistivitas kembali naik dan semakin tinggi seiring bertambahnya kedalaman pada pengukuran lintasan tersebut. Berdasarkan susunan lapisan pada sistem panas bumi bahwa di bawah batuan penudung terdapat daerah reservoir pada kedalaman kurang lebih 2000 sampai dengan 3000 meter. Pada daerah reservoir terdapat perpindahan panas secara konveksi. Air akan masuk ke bawah permukaan karena adanya gaya gravitasi dan ketika air kontak dengan sumber panas maka akan terjadi perpindahan panas yang menyebabkan temperatur air meningkat sehingga air menjadi lebih ringan (Saptaji, 2001). Sumber panas berada di bawah reservoir sehingga air yang megalir ke dalam daerah reservoir dapat meningkat suhunya dan bisa menjadi uap yang dapat keluar dari lapisan bawah permukaan tersebut.

Mata air panas Cubadak berada di dekat titik ukur MTCB-11, dimana terlihat terdapat perbedaan nilai resistivitas dari arah barat daya ke timur laut. Perbedaan nilai resistivitas ini dapat diduga bawah terdapat patahan di bawah permukaan daerah tersebut. Ini didukung dengan munculny mata air panas Cubadak. Semakin kea rah timur laut nilai resistivitas di bawah permukaan memiliki sebaran yang normal yaitu tidak terdapat penurunan resistivitas terhadap kedalaman. 

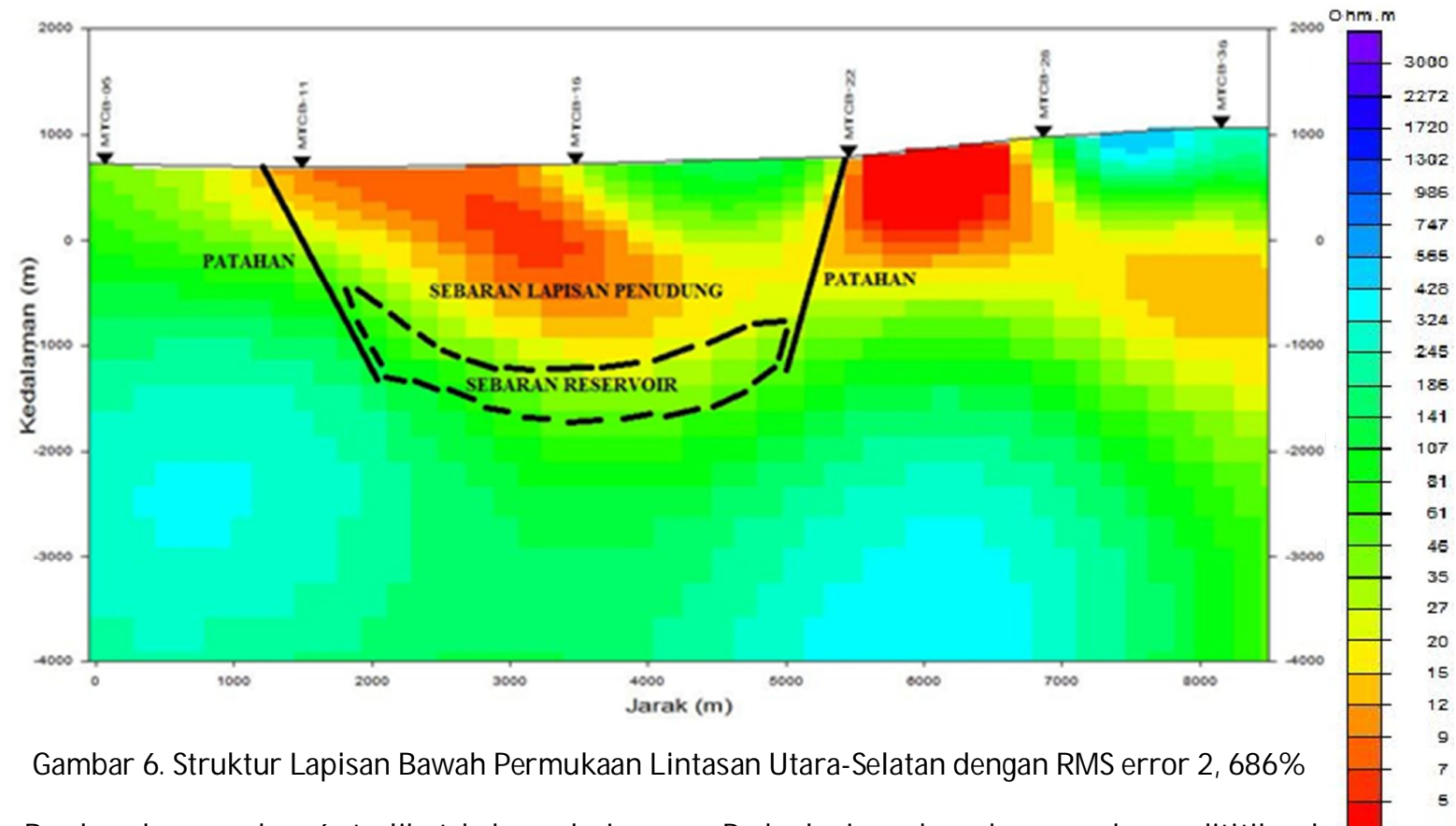

Berdasarkan gambar 6. terlihat bahwa dari lapisan permukaan nilai resistivitas rendah berada di rentang $7 \Omega \mathrm{m}$ sampai dengan $20 \Omega \mathrm{m}$. Semakin dalam terdapat peningkatan nilai resistivitas secara perlahan. Tetapi pada lapisan bawah permukaan antara titik ukur MTCB-16 dan MTCB-22 terdapat perbedaan resistivitas yang menurun pada kedalaman sekitar 1000 meter. Resistivitas permukaan pada lintasan antara titik ukur MTCB-16 dan MTCB-22 berada disekitar nilai $35 \Omega \mathrm{m}$ sampai dengan $61 \Omega \mathrm{m}$. Pada kedalaman 1000 meter di daerah tersebut terdapat penurunan resistivitas menjadi antara nilai $15 \Omega \mathrm{m}$ sampai dengan $27 \Omega \mathrm{m}$ dan nilai resistivitas tersebut merambat ke arah selatan (arah titik ukur MTCB-22). Ini bisa menjadi dugaan awal mengenai sebaran panas bumi pada lintasan Utara-Selatan. Dugaan batuan dasar pada lintasan ini memiliki nilai resistivtas sebesar $300 \Omega \mathrm{m}$ sampai dengan $500 \Omega \mathrm{m}$. Pada daerah sekitar titik ukur MTCB-22 juga muncul mata air panas sawah mudik. Sehingga ini dapat diidentifikasi sebagai pengaruh dari keberadaan mata air panas tersebut.

Pada lapisan bawah permukaan titik ukur MTCB-16 juga terdapat dugaan sebaran dari batuan penudung dengan nilai resistivitas sebesar $9 \Omega \mathrm{m}$ sampai dengan $20 \Omega \mathrm{m}$ dan sebaran reservoir dengan nilai resistivitas sebesar $27 \Omega \mathrm{m}$ sampai dengan $80 \Omega \mathrm{m}$. Dapat diduga bahwa bentuk batuan penudung tersebar hingga ke arah selatan. Sebaran resistivitas dari utara-selatan juga memperlihatkan beberapa perbedaan nilai resistivitas yang bervariasi.
Pada lapisan bawah permukaan dititik ukur MTCB-22 juga terdapat dugaan patahan, yang mengakibatkan mata air panas muncul pada daerah tersebut.

\section{Kesimpulan}

Pada lintasan Barat Daya-Timur Laut terdapat 3 lapisan yang teridiri dari batuan penudung, reservoir dan batuan dasar dengan nilai resistivitas masing-masing adalah $5 \Omega \mathrm{m}$ sampai dengan $12 \Omega \mathrm{m}, 60 \Omega \mathrm{m}$ sampai dengan $180 \Omega \mathrm{m}$ dan $300 \Omega \mathrm{m}$ sampai dengan $700 \Omega \mathrm{m}$. Pada lintasan Utara-Selatan terdapat 3 lapisan yang terdiri dari batuan penudung, reservoir dan batuan dasar dengan nilai resistivitas masing-masing adalah $7 \Omega \mathrm{m}$ sampai dengan $20 \Omega \mathrm{m}, 30 \Omega \mathrm{m}$ sampai dengan $100 \Omega \mathrm{m}$ dan $300 \Omega \mathrm{m}$ sampai dengan $500 \Omega \mathrm{m}$.

\section{Daftar Pustaka}

Agung, L., 2009, Pemodelan Sistem Geothermal dengan Menggunakan Metode Magnetotelurik di Daerah Tawau, Sabah, Malaysia, Universitas Indonesia, Program Studi Fisika, Fakultas Matematika dan Ilmu Pengetahuan Alam, Depok, (Skripsi).

Amriyah, Q., 2012, Pemodelan Data Magnetotellurik Multidimensi untuk Mendelineasi Sistem Geotermal Daerah Tawau, Malaysia, Universitas Indonesia, Program Studi Fisika Fakultas 
Matematika dan Ilmu Pengetahuan Alam, Depok, (Skripsi).

Gaffar, E.Z., Wardhana D.D., Widarto, D.S., 2007, Studi Geofisika Terpadu di Lereng Selatan G. Ungara Jawa Tengah, dan Implikasinya terhadap Struktur Panasbumi, ISSN: 1411- 3082, Jurnal Meteorologi dan Geofisika Vol. 8 No. 2.

Grandis, Dr. H., 1997, Practical Algorithm For One-Dimensional (1-D) Magnetotelluric Forward Modelling, Department Geophysics \& Meteorology, Institut Teknologi Bandung, Journal Geofisika $1 / 97$.

Heditama, D.Z, 2011, Pemprosesan Data Time Series pada Metode Magnetotellurik (MT) Menjadi Data Resistivitas Semu dan Fase Menggunakan MatLab, Universitas Indonesia, Program Studi Fisika, Fakultas Matematika dan Ilmu Pengetahuan Alam, Depok, (Skripsi).

Ika, 2014, Miliki Cadangan Terbesar Dunia, Potensi Panas Bumi Belum Digarap Maksimal, Universitas Gadjahmada, http:/ / ugm.ac.id/ id/ berita/ 9524miliki.cadangan.terbesar.dunia.potensi. panas.bumi.belum.digarap.maksimal (16 Desember 2014)

Kadir, T.V.S., 2011, Metode Magnetotellurik (MT) Untuk Eksplorasi Panas Bumi Daerah Lili, Sulawesi Barat dengan Data Pendukung Metode Gravitasi, Universitas Indonesia, Kekhususan Geofisika Program Studi Fisika, Fakultas Matematika dan Ilmu Pengetahuan Alam, Depok, (Skripsi).

Nurhadi, M., Widodo, S., Soetoyo, Sulaeman, B. 2009, Penyelidikan Terpadu Daerah Panas Bumi Cubadak, Kabupaten Pasaman, Sumatera Barat, Prosiding Hasil Kegiatan Lapangan Pusat Sumber Daya Geologi Tahun 2009, Bandung.

Mwakirani, R., 2012, Magneto-tellurik (MT) Data Processing, Short Course VII on Exploration for Geothernal Resources, United Nations University-Geothernal Training Programme, Geothermal Development, and Kenya Electricity Generating Co., Ltd., Kenya.

Saptaji, Ir. N.M. Ph.D, 2001, Tehnik Panas Bumi, Institud Teknologi Bandung, Departemen Teknik Perminyakan, Fakultas Ilmu Kebumian dan teknologi Mineral, Bandung.

Satrio, A., Koesuma, S., 2012, Identifikasi Panasbumi di Daerah Ngijo dan Pablengan Karanganyar Menggunakan Metode Audio Magnetotelurik, ISSN:
2089-0133, Indonesia Journal of Applied Physics Vol. 2. No.2: 198.

Simpson, F. dan Bahr, K., 2005, Practical Magnetotellurics, Cambridge University Press.

Siripunvaraporn, W., 2006, WSINV3DMT version 1.0.0 for Single Processor Machine: User Manual, Department of Physics, Faculty of Science, Mahinol University, Thailand.

Tim Penyusun, 2009, Penyelidikan Geokimia Daerah Panas Bumi Cubadak Kabupaten Pasaman, Sumatera barat, Pusat Sumber Daya Geologi, Bandung.

Tim Penyusun, 2011, Survei Magnetotellurik Daerah Panas Bumi Cubadak, Kabupaten Pasaman Provinsi Sumatera Barat, Pusat Sumber Daya Geologi, Bandung. 